\title{
The relationship between teacher candidates' pedagogical competence perceptions and their attitudes about teaching profession
}

\author{
Abdullah Adigüzel \\ Düzce University, Faculty of Education, Düzce, Turkey, abdullahadiguzel@duzce.edu.tr
}

\begin{abstract}
The purpose of this study is to determine teacher candidates' pedagogical competence perceptions and their attitudes about teaching profession. The universe of the study is composed of 500 students registered to Harran University Pedagogical Formation Education Certificate Program in 2014-2015 academic years, spring term. Out of 500 surveys distributed, only 487 surveys were included in the analysis. Teacher candidates' attitudes about teaching profession were found to be at medium level. Although their attitudes about teaching profession were higher than their pedagogical competence levels, they were not at the expected level. When teacher candidates' pedagogical competence perceptions and their attitudes about teaching profession were analyzed comparatively, the average of their attitudes about teaching profession were found to be higher than their pedagogical competence perceptions. However, their attitudes and pedagogical competence perceptions were not at the expected level. There was found a significant and high level positive relationship between teachers' pedagogical competence perceptions and their attitudes about teaching profession.
\end{abstract}

Keywords teacher candidate, pedagogical, attitude, pedagogical competence perception,

\section{Öğretmen adaylarının pedagojik yeterlik algıları ile öğretmenlik mesleğine iliş̧kin tutumları arasındaki iliş̧ki}

ÖZ Bu araştırmanın amacı, öğretmen adaylarının pedagojik yeterlik algıları ile öğretmenlik mesleğine ilişkin tutumları arasındaki ilişkiyi belirlemektir. Araştırmanın çalışma evrenini, Harran Üniversitesi Pedagojik Formasyon Eğitimi Sertifika Programına 2014-2015 öğretim yılı bahar döneminde kayıt yaptıran 500 öğrenci oluşturmaktadır. Çalışmada, adaylara gönderilen 500 ölçme aracından 487 tanesi değerlendirilmiştir. Öğretmen adaylarının öğretmenlik mesleğine ilişkin tutumlarının orta düzeyde olduğu belirlenmiştir. Öğretmen adaylarının öğretmenlik mesleğine ilişkin tutumları, pedagojik yeterlik algılarından daha yüksek olmasına rağmen beklenilen düzeyde olmamıştır. Öğretmen adaylarının pedagojik yeterlik algıları ile öğretmenlik mesleğine ilişkin tutumları karşılaştırmalı olarak incelendiğinde; Öğretmen Adaylarının Öğretmenlik Mesleğine İlişkin Tutum ortalamalarının, Pedagojik Yeterlik Algılarından daha olumlu olduğu görülmüştür. Ancak, öğretmen adaylarının hem öğretmenlik mesleğine ilişkin tutumları hem de pedagojik yeterlik algıları beklenilen düzeyde olmadığı sonucuna ulaşılmıştır. Öğretmen adaylarının pedagojik yeterlik algıları ile öğretmenlik mesleğine ilişkin tutumları arasında yüksek düzeyde, pozitif yönde anlamlı bir ilişkinin olduğu görülmüştür.

Anahtar Öğretmen adayl, pedagoji, tutum, pedagojik yeterlik algısl, Kelimeler

Cite This

Adıgüzel, A., (2017). The relationship between teacher candidates’ pedagogical

Article: competence perceptions and their attitudes about teaching profession, Turkish Journal of Education. 6(3), 113-128. DOI: 10.19128/turje.296481 


\section{EXTENDED SUMMARY IN ENGLISH}

It is important to note that teachers, ideal adult model for children and youngsters, have a certain impact on students not only through what they teach but also through their attitudes and behaviors (Oktay, 1999). From this point of view, teaching profession is known to require cognitive competences such as knowledge, skills along with emotional competences such as attitude and values (Girgin, Akamca, Ellez \& Oğuz, 2010). Teachers are expected to respond to the needs of information society of today and be a model for individuals for whom they assume responsibility and be open to innovation and development and have an ability of using modern teaching methods and technology (Bıçak \& Nartgün, 2009; Tanel, Şengören \& Tanel, 2007). Also, it is important that teachers have positive attitude about their profession and realize the roles expected of them (Eren, Çelik \& Oğuz, 2014; Kocaarslan, 2014). To be successful in teaching profession which requires patience, devotion and continuous work, it is vital to perform this job with love and willingness (Aşkar \& Erden, 1987). Within this framework, it has been an issue of wonder to search the relationship between teacher candidates' pedagogical competence and their attitudes about teaching profession, the determinant of success in the profession. This study has been realized to find out this relationship.

The purpose of this study is to determine teacher candidates' pedagogical competence perceptions and their attitudes about teaching profession. These questions below have been tried to be answered throughout the study:

1. What are the pedagogical competence perceptions of teacher candidates?

2. Do their pedagogical competence perceptions display significant difference according to their personal characteristics?

3. What are their attitudes about teaching profession?

4. Do their attitudes about teaching profession display significant difference according to their personal characteristics?

5. Is there any significant relationship between their pedagogical competence perceptions and their attitudes about teaching profession?

\section{Methodology}

The universe of the study is composed of 500 students registered to Harran University Pedagogical Formation Education Certificate Program in 2014-2015 academic year, spring term. Out of 500 surveys distributed, only 487 surveys were included in the analysis. The first scale used in the study is attitude scale about teaching profession. The scale's original reliability coefficient is 0,930 and calculated reliability coefficient is 0.979 . The second scale in the study is the scale of pedagogical competence perception, which was developed during the research process with a calculated reliability coefficient of 0.895 . Kolmogorov-Smirnov $\mathrm{Z}$ test was employed for the data in both scales separately to determine if there was a normal distribution. Kolmogorov-Smirnov Z test values for the Scale of Pedagogical Competence Perception were found to be between 3.73 and 5.24 while they were between 3.57 and 5.41 for the Scale of Attitudes about Teaching Profession. These values show that all the data obtained from both scales exhibit normal distribution in terms of all variables in the study.

\section{Findings and Conclusions}

Teacher candidates' pedagogical competence perceptions were generally found to be at medium level. In terms of sub-dimensions of the pedagogical competence, the domain in which participants feel themselves the weakest is "Lesson Completion Activities" followed by "Pre-Lesson Activities ", "Lesson Preparation Activities" and "Lesson Development Activities". In general, the pedagogical competence could be said to be at the level not expected of the teacher candidates. In terms of lesson completion activities, it was understood that there is a serious need of knowledge and skill.

The pedagogical competence perceptions of teachers were not found to show any significant difference according to their gender, marital status, branch, reason of choice for teaching profession, intended use of internet and age. Indeed, forms of behavior, knowledge and skills required by the teaching profession may not be expected to show any difference according to the teacher candidates' personal characteristics.

Teacher candidates' attitudes about teaching profession were found to be at medium level. Although their attitudes about teaching profession were higher than their pedagogical competence levels, they 
were not at the expected level. Teacher candidates' attitudes about teaching profession showed no statistically significant difference according to their marital status, but there was found a significant difference in favor of male candidates in terms of gender. Teacher candidates' attitudes for teaching profession showed significant differences according to their branches, the reason of choice for this profession and intended use of internet. Regarding the branch variable of the teacher candidates, there was found a significant difference in favor of the candidates of biology branch in comparison with the participants in other branches. Thus, teacher candidates' attitudes towards teaching profession in biology branch could be said to be more positive than the other teacher candidates in other branches. Regarding the reason why participants preferred teaching profession, it was seen that the difference was in favor of those who chose this profession for the job opportunities in this domain compared to those who chose this profession at their own request. Actually, this was not an expected result. Generally, the teacher candidates who choose teaching department with their own will or personal decision are expected to have more positive attitudes about teaching profession. However, the result in this study show that the teacher candidates who chose teaching department for its potential in finding a job have more positive attitudes towards teaching profession. There was also found a significant difference according to the intended use of internet. The difference was in favor of the teacher candidates who use internet for research purposes, compared to the others who use internet for other reasons. The teacher candidates using internet for research purposes have more positive attitudes towards teaching profession.

When teacher candidates' pedagogical competence perceptions and their attitudes about teaching profession were analyzed comparatively, the average of their attitudes about teaching profession were found to be higher than their pedagogical competence perceptions. However, their attitudes and pedagogical competence perceptions were not at the expected level. There was found a significant and high level positive relationship between teachers' pedagogical competence perceptions and their attitudes about teaching profession. The attitudes about teaching profession account for more than fifty percent of total variance of teacher candidates' pedagogical competence perceptions. The regression coefficients show that teacher candidates' pedagogical competence perceptions predict their attitudes about teaching profession significantly. These results suggest a necessity for a longer period of pedagogic formation education for teacher candidates if acquisition of knowledge, attitude and values required by teaching profession is intended. 


\section{GİRIŞ}

Tarihi süreç içerisinde öğretmen yetiştirme, eğitim sistemlerinin en önemli konusu olmuştur. Çünkü eğitim etkinliklerinde amaçlar ne kadar iyi belirlenirse belirlensin, dersin içeriği ne kadar işlevsel seçilip organize edilirse edilsin, amaçlar ve içerik iyi yetişmiş öğretmenler tarafından yürütülmedikçe, eğitimden beklenen başarının alınması mümkün değildir (Sünbül, 2001; Üstüner, 2006). Günümüzde öğretmenlik mesleği, eğitim sektörüyle ilgili sosyal, kültürel, ekonomik, bilimsel ve teknolojik boyutlara sahip, alanda özel uzmanlık bilgi ve becerisini temel alan akademik çalışma ve mesleki formasyon gerektiren, profesyonel statüde bir uğraşı alanıdır (Kara \& Sağlam, 2014; Erden 1998). Bu bağlamda öğretmen, resmi ya da özel bir eğitim kurumunda öğrencilerin öğrenme yaşantılarına kılavuzluk etmek ve yön vermek amacı ile görevlendirilmiş kişi olarak tanımlanır (Öncül, 2000). Böylece öğretmenlik, bir meslek ekseni içinde tanımlandı̆̆ 1 görünmektedir (Tufan \& Güdek 2008). Öğretmen, örgün eğitim kurumlarında öğretimi sağlayan ve belli bir program çerçevesinde planlı eğitim etkinlikleri düzenleyerek öğrencilerde programlar doğrultusunda istendik davranış değişikliği meydana getiren kişi olarak da tanımlanabilir (Erden, 1998). Güngör (1990) öğretmenin görevini, "Öğrencideki yeteneği ortaya çıkarmak ve onun izlenmesine yardımc1 olmaktır" şeklinde tanımlamaktadır (Güngör, 1990). Çocuk ve gençliklerin ideal yetişkin modeli olan öğretmenin, sınıfta öğrettikleri kadar genel tutum ve davranışlarının da öğrenciler üzerinde etkili olacağını unutmamak gerekir (Oktay, 1999). Böylece öğretmenliğin bilgi, beceri gibi bilişsel alan yeterliliklerinin yanı sıra tutum ve değer gibi duyuşsal alan yeterliklerini de gerektiren bir meslek olduğu bilinmektedir (Girgin, Akamca, Ellez \& Oğuz, 2010). Bu denli önemli olan öğretmenlik mesleği, doğal olarak uzmanlaşmay1 ve profesyonelleşmeyi gerektirmektedir.

Öğretmen adaylarının, öğretmenlik mesleğine ilişkin görüşlerini pekiştirmek ve öğretmenlik ruhunu benimsemelerine katkıda bulunmak için, gerek fakültede verilen derslere ve gerekse Millî Eğitim Bakanlığına bağlı okullarda yapılan uygulama çalışmalarına ağırlık verilmelidir (Gürbüztürk \& Genç, 2004; Tekerek \& Polat, 2011). Bu bağlamda bir dersin uygulanmasında en önemli aşama konuya giriş aşamasıdır ve öğretmenin bu konuda yetkin olması gerekir (Lundgren, Scheckle, \& Zinn, 2015). Çünkü öğretmenlerin günümüz bilgi toplumunun ihtiyacına cevap verebilen, sorumluluğunu üstlendiği bireylere model olabilen, değişimlere uyum sağlayan, yeniliklere ve gelişmelere açık olan, çağdaş öğretim yöntem ve teknolojilerini uygulama becerilerine sahip olmaları beklenmektedir (Bıçak \& Nartgün, 2009; Tanel, Şengören \& Tanel, 2007). Yeni teknolojilerin pedagojik ilkelere uygun olarak kullanılması motivasyonu artırmaktadır (Sherman \& Howard, 2012; Chigona \& Davids 1014). Ayrica öğretmenlerin mesleklerine ilişkin olumlu tutum içinde olmaları, kendilerinden beklenen rolleri yerine getirmeleri de önemlidir (Eren, Çelik \& Oğuz, 2014; Kocaarslan, 2014). Sabır, özveri ve sürekli çalışma gerektiren öğretmenlik mesleğinde başarılı olabilmek için bu mesleği severek ve isteyerek yapmak çok önemlidir (Aşkar \& Erden, 1987).

Öğretmen adaylarına, öğretmenlik mesleğinin gerektirdiği bilgi, beceri, tutum ve değerlerin kazandırılmasına yönelik verilen eğitime akademik olarak "öğretmenlik meslek bilgisi" denmesine rağmen halk arasında pedagojik formasyon olarak bilinmektedir. Yunancada "Paidagoge" olarak bilinen pedagoji kavramı "çocuk yönetmek", "çocuklara öğretmenin bilim ve sanatı" ve "eğitim bilim ve teorisi" anlamlarına gelmektedir. Formasyon ise İngilizce "Formation" kelimesinden gelmektedir. Türkçesi, biçimlenme, yetişim ve oluşum olarak tanımlanabilir (TDK, 2014). Pedagojik Formasyon bir bütün olarak düşünüldügünde, öğretme öğrenme süreçlerini gerçekleştirmek için sahip olunmas1 gereken yeterlik yada öğretmen olabilmek için alınması gereken bir eğitim olarak tanımlanabilir (Yapıcı \& Yapıc1, 2013). Bu anlamda öğretmen adaylarının aldıkları pedagojik formasyon eğitimi sonucunda, bilişsel, duyuşsal ve psikomotor alanda mesleğe uygun davranış değişikliği meydana getirmeleri, etkili öğretmenlik nitelikleri içerisinde neyi, nasıl ve ne zaman öğretecekleri gibi stratejik bilgileri edinmeleri gereklidir (Doğan \& Çoban, 2009). Nitelikli öğretmen yetiştirme özellikle son yıllarda eğitim sisteminin en önemli sorunlarından biri olmuştur (Çapri \& Çelikkaleli, 2008). Bu nedenle öğretmenlerin yalnızca bilişsel alanda gelişmeleri yeterli olmamakta, bu mesleği sevgi ve istekle yapmak da büyük önem taşımaktadır (Çeliköz \& Çetin, 2004). Toplumsal değerlerin korunması, sürdürülmesi ve yeni değerlerin kazandırılmasında öğretmen en önemli öğedir (Çapraz \& Samanc1 2014). Öğretmenlerde bulunması arzulanan bütün bu özellikler öğretmen eğitimin en önemli boyutu olan pedagojik farmasyon kapsamında değerlendirilmektedir. Böylece öğretmenlik mesleğinin gerektirdiği davranış formlarını içeren pedagojik yeterlik ile öğretmenlik mesleğinde başarının 
belirleyicisi olan öğretmenlik mesleğine ilişkin tutumların birbirleriyle ilişkisi ve birbirlerini etkileme durumları merak konusu olmuştur. Bu çalışma, bu ilişkiyi belirlemek amacıyla gerçekleştirilmiştir.

$\mathrm{Bu}$ araştırmanın amacı, öğretmen adaylarının pedagojik yeterlik algıları ile öğretmenlik mesleğine ilişkin tutumları arasındaki ilişkiyi belirlemektir. Bu genel amaç kapsamında şu sorulara yanıt aranmıştır:

1. Öğretmen adaylarının pedagojik yeterlik algıları nasıldır?

2. Öğretmen adaylarının pedagojik yeterlik algıları onların kişisel özelliklerine göre anlamlı düzeyde farkl111k göstermekte midir?

3. Öğretmen adaylarının öğretmenlik mesleğine ilişkin tutumları nasıldır?

4. Öğretmen adaylarının öğretmenlik mesleğine ilişkin tutumları onların kişisel özelliklerine göre anlamlı düzeyde farkl1lık göstermekte midir?

5. Öğretmen adaylarının pedagojik yeterlik algıları ile öğretmenlik mesleğine ilişkin tutumları arasında anlamlı bir ilişki var mıdır?

\section{YÖNTEM}

$\mathrm{Bu}$ çalışma tarama modelinde olup tekil ve ilişkisel teknikler kullanılarak gerçekleştirilmiştir. Tekil tarama tekniği ile öğretmen adaylarının pedagojik yeterlik algıları ve öğretmenlik mesleğine ilişkin tutumlarına yönelik görüşleri belirlenmiştir. İlişkisel tarama tekniğiyle de öğretmen adaylarının pedagojik yeterlik algıları ile öğretmenlik mesleğine ilişkin tutumları arasındaki ilişkiye bakılmıştır.

\section{Evren ve Örneklem}

Araştırmanın çalışma evrenini, Harran Üniversitesi Pedagojik Formasyon Eğitimi Sertifika Programına 2015-2016 öğretim yılı bahar döneminde çeşitli branşlarda kayıt yaptıran 500 öğrenci oluşturmaktadır. Çalışmada öğretmen adaylarının tamamına ulaşılması hedeflendiğinden örneklem alma yoluna gidilmemiş ve tüm öğretmen adaylarına er iki ölçme aracı gönderilmiştir. Dönen ölçme araçlarından 487 tanesi değerlendirilebilir olarak kabul edilmiştir.

\section{Veri Toplama Araçları}

Bu çalışmada veri toplamak amacıyla iki ölme aracı kullanılmıştır. Ölçme araçlarından ilki Üstüner, M (2006) tarafindan geliştirilen “Öğretmenlik Mesleğine Yönelik Tutum Ölçeği”dir. Bu ölçeğin geliştirilmesi aşamasındaki güvenirlik katsayısı 0,93 olarak belirlenmiştir. Bu çalışmada ise ölçeğin güvenirlik katsayısı 0.979 olarak hesaplanmıştır. Ölçek, 24 madde olumlu, 10 madde ise olumsuz olarak üzere toplam 34 maddeden oluşmaktadır. Olumsuz maddelerin puanlaması ters yönden yapılmıştır. Beşli likert olarak geliştirilen ölçek; Tamamen Katılıyorum, Çoğunlukla Katılıyorum, Orta Düzeyde Katılıyorum, Kısmen Katılıyorum ve Hiç Katılmıyorum şeklinde derecelendirilmiştir. Çalışmada kullanılan ikinci ölçme aracı ise "Pedagojik Yeterlik Algısı Ölçeği”dir. Çalışmanın başında anket olarak tasarlanan ve uygulanan bu ölçme aracı toplanan verilere dayalı olarak ölçek geliştirme sürecine tabi tutulmuştur.

\section{Pedagojik Yeterlik Algısı Ölçeği}

Pedagojik yeterlik algısı ölçeğinde yer alan maddelerin belirlenmesi amacıyla öğretmenlik mesleğinin gerektirdiği davranış formları alanyazına dayalı olarak maddeler halinde belirlenmiştir. Daha sonra bu maddeler öğretmen adaylarına sunularak doğrulanmış ve beşli Likert tipi bir ölçek haline getirilerek 55 maddeden oluşan ilk taslak oluşturulmuştur. Ölçeğin, geçerlik ve güvenirlik çalışması için Harran Üniversitesi Sürekli Eğitim Merkezince açılan Pedagojik Formasyon Programına kayıtlı 500 kişilik gönüllü bir öğrenci grubuna uygulanmıştır. Ölçekteki seçenekler ve seçeneklere ilişkin sinırlar; "Her zaman" için 5, "Çoğu zaman" için 4, "Bazen” için 3, "Ara sıra" için 2 ve "Hiçbir zaman” için 1 biçiminde sıralanmış ve puanlanmıştır. Ölçek, öğretmen adaylarının pedagojik yeterlik algılarına yönelik olduğu için ölçekte yer alan maddeler olumlu ve olumsuz olarak gruplandırılmamıştır. Pedagojik yeterlik algısı Ölçeğinin yapı geçerliliğinin sağlanması amacıyla Açımlayıcı Faktör Analizinden (Exploratory Factor Analysis- EFA) yararlanılmıştır. Ölçeğe ilişkin toplanan verilerin faktör analizine uygunluğunun belirlenmesi amaciyla ölçekte bulunan 55 madde üzerinde bir analiz yapılmış ve analiz sonuçlarına göre KMO (Kaiser- Meyer-Olkin Measure of Sampling Adequacy) değeri .842, Bartlett Testi 3.353 olarak hesaplanmıştır. Yapılan ilk analiz 
sonucunda hiçbir faktörde kabul düzeyinin üzerinde yük değeri alamayan maddeler ile iki faktör arasındaki yük değerleri .1'den küçük olan maddeler işlemeyen maddeler olarak kabul edilmiş ve ölçekten çıkarılmıştır. Bu yolla ölçekten çıkarılan madde sayısı 26'dır. İlk faktör analizi sonucu işler durumda bulunan ve ölçeğe alınan 29 madde üzerinde analiz tekrarlanmıştır. İkinci faktör analizi sonucunda korelasyon matrisinden faktör çıkarılıp çıkarılamayacağını belirlemek amacıyla ölçeğin Kaiser Meyer Olkin (KMO) katsayısı hesaplanmıs ve Bartlett's Sphericity testi uygulanmıştır. Yapılan analiz sonucunda, KMO katsayıs1 .886 olarak hesaplanırken, Bartlett's Sphericity değerinin de $\left(\chi^{2}=5.866, \mathrm{p}<.01\right)$ olduğu belirlenmiştir. Bartlett's Sphericity anlamlılık değerinin .05 'ten küçük olması korelasyon matrisinden faktör çıkarılabileceğini göstermektedir (Çokluk, Şekercioğlu ve Büyüköztürk, 2010). Açımlayıcı Faktör Analizine göre Pedagojik Yeterlik Algısı Ölçeğine ilişkin yapılan ikinci faktör analizi işlemleri sonucunda elde edilen 29 maddenin birbirinden bağımsız anlamlı faktörlere ayrılıp ayrılmadığının belirlenmesi amacıyla asal eksenlere göre döndürülmüş ve temel bileşenler analizi yapılmıştır. Yapılan döndürme işlemlerinin sonucunda dört faktör belirlenmiştir. Bu faktörlerde toplanan madde sayısı ise; birinci faktörde 4, ikinci faktörde 8, üçüncü faktörde 10 ve dördüncü faktörde 7'tir. Bu faktörler bir ders işleyişinin sistematik yapısı dikkate alınarak birinci faktör için "Ders öncesi hazırlık etkinlikleri”, ikinci faktör için "derse giriş etkinlikleri”, üçüncü faktör için “ dersi geliştirme etkinlikleri” ve dördüncü faktör için "dersi sonuçlandırma etkinlikleri”" olarak isimlendirilmiştir. Faktörlerin temel bileşenler analizini yapmak amacıyla yapılan döndürme işlemi sonucunda ölçekte yer alan maddelerin faktör yükleri hesaplanmış ve elde edilen değerler Tablo 1'de verilmiştir.

Tablo 1

Pedagojik Yeterlik Algısı Ölçeğinin Asal Eksenlere Göre Döndürülmüs Temel Bileşenler Analizi Yöntemindeki Maddelerin Faktör Yükleri

\begin{tabular}{|c|c|c|c|c|c|c|}
\hline $\begin{array}{l}\text { Madde } \\
\text { No }\end{array}$ & $\begin{array}{l}\text { Döndürme öncesi } \\
\text { Faktör Yük } \\
\text { Değerleri }\end{array}$ & $\begin{array}{c}\text { Faktör } 1 \\
\text { Ders ncesi } \\
\text { hazırlık }\end{array}$ & $\begin{array}{c}\text { Faktör } 2 \\
\text { Derse giriş } \\
\text { etkinlikleri }\end{array}$ & $\begin{array}{c}\text { Faktör } 3 \\
\text { Geliş̧irme } \\
\text { etkinlikleri }\end{array}$ & $\begin{array}{c}\text { Faktör } 4 \\
\text { Sonuç } \\
\text { etkinlikleri }\end{array}$ & $\begin{array}{c}\text { Madde } \\
\text { Toplam Test } \\
\text { Korelasyonu }\end{array}$ \\
\hline 2 & .745 & .582 & & & & .676 \\
\hline 3 & .676 & .718 & & & & .632 \\
\hline 4 & .656 & .660 & & & & 642 \\
\hline 5 & .765 & .781 & & & & .636 \\
\hline 8 & .646 & .725 & & & & .642 \\
\hline 9 & .665 & .737 & & & & .665 \\
\hline 11 & .607 & .664 & & & & 557 \\
\hline 12 & .817 & .748 & & & & .635 \\
\hline 13 & .642 & & .648 & & & .538 \\
\hline 14 & .666 & & .725 & & & 612 \\
\hline 15 & .738 & & .723 & & & .718 \\
\hline 16 & .652 & & .536 & & & 612 \\
\hline 34 & .728 & & .724 & & & 652 \\
\hline 36 & .725 & & .462 & & & 643 \\
\hline 37 & .691 & & .712 & & & 643 \\
\hline 38 & .725 & & .722 & & & .665 \\
\hline 39 & .574 & & .586 & & & .524 \\
\hline 41 & .697 & & .566 & & & .634 \\
\hline 42 & .756 & & .578 & & & .693 \\
\hline 43 & .584 & & & .684 & & .534 \\
\hline 44 & .759 & & & .732 & & .729 \\
\hline 45 & .665 & & & .616 & & 625 \\
\hline 49 & .729 & & & .589 & & .662 \\
\hline 50 & .796 & & & .573 & & .733 \\
\hline 51 & .722 & & & & .699 & .664 \\
\hline 52 & .726 & & & & .576 & .682 \\
\hline 53 & .626 & & & & .666 & .589 \\
\hline 54 & .687 & & & & .786 & .657 \\
\hline 55 & .684 & & & & .766 & .634 \\
\hline
\end{tabular}

Tablo 1 incelendiğinde pedagojik yeterlik algıSı ölçeğini oluşturan maddelerin döndürme öncesi 
faktör yük değerleri .584 ile .817 arasında değişirken, döndürme işlemi sonrası faktör yük değerlerinin .524 ile .786 arasında değiştiği görülmektedir. Pedagojik Yeterlik Algısı Ölçeğinde yer alan maddelerin ayırt ediciliklerini belirlemek amacıyla madde-toplam test korelasyonları incelenmiştir. Tablo 1'de görüldügüu gibi ölçeğin madde-toplam test korelasyon değerleri .524 ile .733 arasında değişmektedir. Genel olarak ölçekte madde-toplam test korelasyon değeri .30’dan yüksek olan maddelerin ayırt ediciliklerinin iyi olduğu (Şencan, 2005) düşünüldüğünde, Pedagojik Yeterlik Algisı Ölçeğinde yer alan maddelerin ayırt ediciliklerinin yüksek olduğu söylenebilir. Pedagojik Yeterlik Algısı Ölçeğine ilişkin güvenirlik katsayıları, özdeğerler ve açıklanan varyans oranlarına ilişkin sayısal değerler Tablo 2'de verilmiştir.

Tablo 2

Pedagojik Yeterlik Algısı Ölçeğinin Alt Boyutlarına Göre Güvenirlik Katsayıları, Özdeğerlendirme ve Açıklanan Varyans Oranlarl

\begin{tabular}{|c|c|c|c|c|c|}
\hline Alt Boyutlar & $\begin{array}{l}\text { İşleyen } \\
\text { Maddeler }\end{array}$ & $\begin{array}{l}\text { Çıkarılan } \\
\text { maddeler }\end{array}$ & $\begin{array}{l}\text { Faktörlerin } \\
\text { Güvenirlik } \\
\text { Katsayıları }\end{array}$ & $\begin{array}{l}\text { Faktörlerin } \\
\text { Özdeğerleri }\end{array}$ & $\begin{array}{c}\text { Faktörlerin } \\
\text { Açıklanan } \\
\text { Varyans Oranları }\end{array}$ \\
\hline $\begin{array}{l}\text { Ders Öncesi Hazırlık } \\
\text { Etkinlikleri }\end{array}$ & 2. 3. 4. 5 . & 6 & .763 & 8.86 & 22.25 \\
\hline Derse Giriş Etkinlikleri & $\begin{array}{l}\text { 8. 9. } 11.12 . \\
\text { 13. } 14.15 . \\
\text { 16. } \\
\text { 34. 36. } 37 .\end{array}$ & 7 & .668 & 3.44 & 36.22 \\
\hline $\begin{array}{l}\text { Dersi Geliştirme } \\
\text { Etkinlikleri }\end{array}$ & $\begin{array}{l}\text { 38. 39. } 41 . \\
\text { 42. } 43.44 . \\
45 .\end{array}$ & 9 & .862 & 2.24 & 48.02 \\
\hline $\begin{array}{l}\text { Dersi Sonuçlandırma } \\
\text { Etkinlikleri }\end{array}$ & $\begin{array}{l}49.50 .51 . \\
52.53 .54 . \\
55 .\end{array}$ & 4 & .818 & 1.48 & 54.63 \\
\hline
\end{tabular}

Pedagojik Yeterlik Algısı Ölçeğinin yapı geçerliliğini belirlemek amacıyla yapılan faktör analizi sonucu ölçeğin alt boyutlarında işleyen maddeler belirlenmiş ve işlemeyen maddeler ölçekten çıkarılmıştır. Buna göre; "Ders öncesi hazırlık etkinlikleri” alt boyutunda 2., 3., 4. ve 5. maddeler yer alırken işlemeyen altı madde ölçekten çıkarılmıştır. "Giriş etkinlikleri” alt boyutunda 8.,9.,11.,12.,13.,14.,15. ve 16. maddeler yer almış ve işlemeyen yedi madde ölçekten çıkarılmıştır. "Geliştirme etkinlikleri" alt boyutunda 34.,36., 37., 38., 39., 41., 42., 43., 44. ve 45. maddeler yer almış ve işlemeyen dokuz madde ölçekten çıkarılmıştır. "Sonuç etkinlikleri” alt boyutunda 49., 50., 51., 52.,53.,54. ve 55. maddeler yer alırken, işlemeyen dört madde ölçekten çıkarılmıştır. Genel olarak kabul düzeyinin üzerinde yük değeri alamayan maddeler ile iki faktör arasındaki yük değerleri .1'den küçük olan toplam 26 madde ölçekten çıkarılmıştır. Yapılan analizler sonucu yeterli düzeyde koşulları sağladığı düşünülen 29 madde ile Pedagojik Yeterlik Algısı Ölçeği geliştirilmiştir.

Ölçeğin uygulanması ile elde edilen puanların güvenirliği Cronbach Alpha güvenirlik kat sayısı ile hesaplanmıştır. Cronbach Alpha, ölçeğin tümü ve ölçeğin her bir alt boyutu için iç tutarlık anlamında kullanılan bir güvenirlik katsayısı hesaplama biçimidir (Büyüköztürk, 2004). Buna göre, ölçeğe ilişkin yapılan güvenirlik hesaplamalarında, ölçeğin bir bütün olarak Cronbach Alpha güvenirlik katsayısı .895 olarak belirlenmiştir. Ölçeğin alt boyutlarına ilişkin Cronbach Alpha güvenirlik katsayıları; "Derse hazırllk" alt boyutu için .763, "Giriş etkinlikleri” alt boyutu için .668, "Geliştirme etkinlikleri” alt boyutu için .862 ve "Sonuç etkinlikleri” alt boyutu için .818 olarak hesaplanmıştır. Cronbach Alpha değerlerinin .700'ün üzerinde olması güvenirlik için yeterli olduğu kabul edilmektedir (Bayram, 2004). Bu sonuçlara göre, Pedagojik Yeterlik Algısı Ölçeğinin yeterli derecede güvenilir olduğu söylenebilir. Diğer taraftan, ölçeğin alt boyutlarını oluşturan faktörlerden birincisinin özdeğeri 8.86, ikincisinin özdeğeri 3.44, üçüncüsünün özdeğeri 2.24 ve dördüncüsünün özdeğeri 1.48 olarak belirlenmiştir. Böylece ölçekte yer alan maddelerin ayırt ediciliklerinin yeterli düzeyde olduğu söylenebilir. Pedagojik Yeterlik Algısı Ölçeğinde yer alan bu dört faktör toplam varyansın 54.63’ünü açıklar niteliktedir. Pedagojik Yeterlik Algısı Ölçeğinin birinci faktörün varyansı $\% 22.25$, ikinci faktörün varyansı \%36.22, üçüncü faktörün varyansı \%48.02 ve dördüncü faktörün varyansı \%54.63 oranında açıklamaktadır. 


\section{Veri Analizi}

Araştırmada, elde edilen verilerin normal dağılım gösterip göstermediğini belirlemek amacıyla her iki ölçek ile toplanan verilere ayrı ayrı Kolmogorov-Smirnov Z testi uygulanmıştır. "Pedagojik Yeterlik Algısı Ölçeği”nin Kolmogorov-Smirnov Z değerleri 3.73 ile 5.24 arasında değişken, “Öğretmenlik Mesleğine Yönelik Tutum Ölçeği"nin Kolmogorov-Smirnov Z değerleri 3.57 ile 5.41 arasında değiştiği görülmüştür. Bu değerler, her iki ölçekle toplanan verilerin tüm değişkenler açısında normal dağılımda olduğunu göstermektedir. Araştırmada alt problemlerin çözümlenebilmesi için aritmetik ortalama ve standart sapma değerleri, ayrıca görüşler arası farkı bulmak için t-testi, tek yönlü varyans analizi (ANOVA), Tukey HSD testlerinden yararlanılmıştır. Değişkenler arasındaki ilişkilerin hesaplanmasında Pearson Momentler Çarpım Korelasyon Katsayısı (r) kullanılmıştır.

\section{BULGULAR ve YORUM}

Araştırmanın bu bölümünde, öğretmen adaylarının Pedagojik Yeterlik Algısı ile Öğretmenlik Mesleğine Yönelik Tutumları arasındaki ilişkiyi belirlemeye yönelik olarak elde edilen verilerin istatistiksel analizleri sonucunda ulaşılan bulgulara ve bu bulguların yorumlarına yer verilmiştir.

\section{Öğretmen Adaylarının Pedagojik Yeterlik Algı Düzeyleri}

Öğretmen adaylarının Pedagojik Yeterlik Algısı ve bu algının kişisel özelliklerine göre farklılık gösterip göstermediğini belirlemek amacıyla toplanan verilerin analizleri yapılmıştır. Öğretmen adaylarının Pedagojik Yeterlik Algılarına ilişkin sayısal veriler Tablo 3'de verilmiştir.

Tablo 3

Öğretmen Adaylarının Pedagojik Yeterlik Algıları Genel ve Alt Boyutlara Göre Görünümü

\begin{tabular}{llllll}
\hline & $\mathrm{n}$ & Minimum & Maximum & $\overline{\mathrm{X}}$ & Ss \\
\hline Pedagojik Yeterlik Algısı & 487 & 2.56 & 3.68 & 3.20 & .533 \\
Derse Hazırlık Etkinlikleri & 487 & 3.13 & 3.57 & 3.30 & .699 \\
Ders Öncesi Etkinlikler & 487 & 2.57 & 3.92 & 3.23 & .592 \\
Dersi Geliştirme Etkinlikleri & 487 & 2.83 & 3.68 & 3.39 & .702 \\
Dersi Sonuçlandırma Etkinlikleri & 487 & 2.56 & 3.26 & 2.86 & .767 \\
\hline
\end{tabular}

Tablo 3'de görüldüğü gibi, öğretmen adaylarının genel olarak Pedagojik Yeterlik Algılarına ilişkin görüşlerinin aritmetik ortalamaları $(\overline{\mathrm{x}}=2.56)$ ile $(\overline{\mathrm{x}}=3.68)$ arasında değiştiği görülmektedir. $\mathrm{Bu}$ bulgular, öğretmen adaylarının kendilerini pedagojik yeterlik açısında orta düzeyde algıladıklarını göstermektedir. Böylece, öğretmen adaylarının Pedagojik Yeterlik açısından kendilerini yeterli görmedikleri ve kendilerine ilişkin algılarının yeterli düzeyde olumlu olmadığı söylenebilir. Öğretmen adaylarının Pedagojik Yeterlik Algılarının alt boyutlarına ilişkin görüşlerinin aritmetik ortalamaları ise; "Derse Hazırlik Etkinlikleri" ( $\bar{x}=3.13-3.57)$, "Ders Öncesi Etkinlikler" ( $\bar{x}=2.57-3.92)$ "Dersi Geliştirme Etkinlikleri” ( $\overline{\mathrm{x}}=2.83-3.68)$ ve "Dersi Sonuçlandırma Etkinlikleri” $(\overline{\mathrm{x}}=2.56-3.26)$ arasında değişmektedir. Bu bağlamda öğretmen adayları kendilerini en zayıf gördükleri alt alan "Dersi Sonuçlandırma Etkinlikleri $(\overline{\mathrm{x}}=2.86)$ " olurken, bunu "Ders Öncesi Etkinlikler $(\overline{\mathrm{x}}=3.23)$ ”, "Derse Hazırlık Etkinlikleri $(\bar{x}=3.30)$ ” ve “Dersi Geliştirme Etkinlikleri $(\bar{x}=3.39)$ ” izlemektedir.

Tablo 4

Öğretmen adaylarının Pedagojik Yeterlik Algllarının; Cinsiyet ve Medeni Durumlarına Göre t-Testi Sonuçları

\begin{tabular}{|c|c|c|c|c|c|c|c|}
\hline & & $\mathrm{n}$ & $\bar{x}$ & Ss & $\mathrm{sd}$ & $\mathrm{t}$ & $\mathrm{P}$ \\
\hline \multirow{2}{*}{ Cinsiyet } & Kadın & 201 & 3.25 & .529 & \multirow{2}{*}{485} & \multirow{2}{*}{1.605} & \multirow{2}{*}{109} \\
\hline & Erkek & 286 & 3.17 & .533 & & & \\
\hline \multirow{2}{*}{ Medeni durum } & Evli & 122 & 3.21 & .523 & \multirow{2}{*}{485} & \multirow[t]{2}{*}{.-218} & \multirow{2}{*}{.827} \\
\hline & Bekar & 365 & 3.20 & .536 & & & \\
\hline
\end{tabular}

Tablo 4'deki verilere göre, öğretmen adaylarının Pedagojik Yeterlik Algıları cinsiyet [t(487) = 1.605, $\mathrm{P}>.05]$ ve medeni durum [t(487) $=-.218, \mathrm{P}>.05]$ değişkenlerine göre anlamlı düzeyde farklılık göstermemiştir. Ancak göreceli olarak kadınların öğretmen adaylarının erkeklere ve evli öğretmen adaylarının ise bekarlara göre pedagojik yeterlik algılarının daha yüksek olduğu söylenebilir. Öğretmen adaylarının, Pedagojik Yeterlik Algılarının; Branş, Öğretmenliği Tercih Nedeni, İnterneti 
Kullanım Amacı ve Yaşlarına göre anlamlı düzeyde farklılık gösterip göstermediği ile ilgili sayısal veriler Tablo 5'te yer almaktadır.

Tablo 5

Öğretmen adaylarının Pedagojik Yeterlik Algllarının; Branş, Öğretmenliği Tercih Nedeni, İnterneti Kullanım Amacı ve Yaşlarına Göre ANOVA Sonuçları

\begin{tabular}{|c|c|c|c|c|c|c|c|c|c|c|}
\hline Uygulama & Değişkenler & $\mathrm{n}$ & $\bar{X}$ & Ss & $\begin{array}{c}\text { Varyansin } \\
\text { Kaynağ1 } \\
\end{array}$ & $\begin{array}{l}\text { Kareler } \\
\text { Top. } \\
\end{array}$ & sd & $\begin{array}{l}\text { Kareler } \\
\text { Ort. }\end{array}$ & $\mathrm{F}$ & $\mathrm{P}$ \\
\hline \multirow{9}{*}{ Branş } & 1.Tarih & 61 & 3.28 & .499 & \multirow{3}{*}{ Grup içi } & \multirow{3}{*}{3.278} & \multirow{3}{*}{7} & \multirow{3}{*}{,468 } & \multirow{9}{*}{1.667} & \multirow{9}{*}{.115} \\
\hline & 2.Edebiyat & 61 & 3.16 & .669 & & & & & & \\
\hline & 3.Matematik & 63 & 3.21 & .559 & & & & & & \\
\hline & 4.Coğrafya & 68 & 3.23 & .514 & \multirow{6}{*}{ Gruplar arası } & \multirow{4}{*}{134.559} & & \multirow{6}{*}{.281} & & \\
\hline & 5. Biyoloji & 60 & 3.09 & .474 & & & \multirow[t]{3}{*}{479} & & & \\
\hline & 6.İlahiyat & 108 & 3.13 & .479 & & & & & & \\
\hline & 7.İktisadi idari & 32 & 3.34 & .446 & & & & & & \\
\hline & 8.Sağlık & 34 & 3.36 & .590 & & \multirow[t]{2}{*}{137.837} & \multirow[t]{2}{*}{486} & & & \\
\hline & Toplam & 487 & 3.20 & .532 & & & & & & \\
\hline \multirow{3}{*}{$\begin{array}{l}\text { Öğretmenliği } \\
\text { Tercih Nedeni }\end{array}$} & $\begin{array}{l}\text { Kendi İsteğim } \\
\text { Aile/Çevre }\end{array}$ & 234 & 3.17 & .556 & Grup içi & .745 & 2 & .373 & \multirow{3}{*}{1.316} & \multirow{3}{*}{.269} \\
\hline & İş Garantisi & 142 & 3.26 & .506 & \multirow{2}{*}{ Gruplar arası } & 137.091 & 484 & \multirow{2}{*}{.283} & & \\
\hline & Toplam & 111 & 3.19 & .512 & & 137.837 & 486 & & & \\
\hline \multirow{5}{*}{$\begin{array}{l}\text { İnternet Kullanma } \\
\text { Amacı }\end{array}$} & 1.Araştırma & 487 & 3.20 & .532 & \multirow{2}{*}{ Grup içi } & \multirow{2}{*}{.509} & \multirow{2}{*}{3} & \multirow{2}{*}{.170} & \multirow{5}{*}{.597} & \multirow{5}{*}{.617} \\
\hline & 2. İletişim & 152 & 3.20 & .537 & & & & & & \\
\hline & 3. Eğlence & 154 & 3.22 & .535 & \multirow{3}{*}{ Gruplar arası } & 137.327 & 483 & \multirow{3}{*}{.284} & & \\
\hline & 4. Bilgi Edinme & 83 & 3.14 & .514 & & $13 \% .321$ & 483 & & & \\
\hline & Toplam & 487 & 3.20 & .532 & & 137.837 & 486 & & & \\
\hline \multirow{5}{*}{ Yaş } & 25 ve alt 1 & 50 & 3.21 & .519 & \multirow{2}{*}{ Grup içi } & \multirow{2}{*}{.501} & \multirow{2}{*}{3} & \multirow{2}{*}{.167} & & \\
\hline & $26-30$ & 339 & 3.22 & .527 & & & & & & \\
\hline & $31-35$ & 75 & 3.16 & .568 & Gruplar arası & 137336 & & & 587 & .624 \\
\hline & 36 ve üzer & 23 & 3.10 & .526 & Gruplar arası & $13 \% .336$ & 483 & .284 & & \\
\hline & Toplam & 487 & 3.20 & .532 & & 137.837 & 486 & & & \\
\hline
\end{tabular}

Tablo 5 genel olarak incelendiğinde, öğretmen adaylarının Pedagojik Yeterlik Algıları; Branş [f(487)=1,667, P>.05], Öğretmenliği Tercih Nedeni f(487)= 1,316, P>.05], İnterneti Kullanım Amacı $\mathrm{f}(487)=, 597, \mathrm{P}>.05]$ ve Yaşlarına $\mathrm{f}(487)=, 624, \mathrm{P}>.05]$ göre anlamlı düzeyde farklılık göstermediğ $\mathrm{i}$ görülmektedir. Böylece öğretmen adaylarının; branş, öğretmenliği tercih nedeni, interneti kullanım amacı ve yaşları gibi kişisel özellikleri onların pedagojik yeterlik algılarını etkilemediği söylenebilir.

\section{Öğretmen Adaylarının Öğretmenlik Mesleğine İlişkin Tutum Düzeyleri}

Öğretmen adaylarının öğretmenlik mesleğine ilişkin tutumlarından elde edilen verilerin analizlerine ve yorumlarına bu başlık altında yer verilmiştir. Öğretmen adaylarının öğretmenlik mesleğine ilişkin tutumlarına ait sayısal veriler Tablo 6'de verilmiştir.

Tablo 6

Öğretmen Adaylarının Öğretmenlik Mesleğine İlişskin Tutumları

\begin{tabular}{lccccc}
\hline & $\mathrm{n}$ & Minimum & Maximum & $\overline{\mathrm{x}}$ & Ss \\
\hline Öğretmenlik Mesleğine İlişkin Tutum & 487 & 2.83 & 3.77 & 3.44 & .842 \\
\hline
\end{tabular}

Tablo 6'da görüldüğü gibi, öğretmen adaylarının genel olarak öğretmenlik mesleğine ilişkin tutumlarının aritmetik ortalamaları, $(\bar{x}=2,83)$ ile $(\bar{x}=3.77)$ arasında değiştiği görülmektedir. $\mathrm{Bu}$ bulgu, öğretmen adaylarının öğretmenlik mesleğine ilişkin tutumlarının orta düzeyde olduğunu göstermektedir. Öğretmen adaylarının öğretmenlik mesleğine ilişkin tutumları onların pedagojik yeterlik algılarından daha yüksek olmasına rağmen beklenilen düzeyde değildir.Öğretmen adaylarının öğretmen adaylarının öğretmenlik mesleğine ilişskin tutumlarının; cinsiyet ve medeni durumlarına göre anlamlı düzeyde farklılık gösterip göstermediği ile ilgili sayısal veriler Tablo 7’de verilmiştir. 
Tablo 7.

Öğretmen Adaylarının Öğretmenlik Mesleğine Ilişkin Tutumlarının; Cinsiyet ve Medeni Durumlarına Göre tTesti Sonuçları

\begin{tabular}{llcccccc}
\hline & & $\mathrm{n}$ & $\overline{\mathrm{x}}$ & $\mathrm{Ss}$ & $\mathrm{sd}$ & $\mathrm{t}$ & $\mathrm{P}$ \\
\hline \multirow{2}{*}{ Cinsiyet } & Kadın & 198 & 3.33 & .873 & \multirow{2}{*}{484} & -2.510 & \multirow{2}{*}{012} \\
\multirow{3}{*}{ Medeni durum } & Erkek & 288 & 3.52 & .815 & & & \\
& Evli & 122 & 3.45 & .848 & \multirow{2}{*}{485} & -088 & .930 \\
& Bekar & 365 & 3.44 & .842 & & & \\
\hline
\end{tabular}

Tablo 7'deki verilere göre, öğretmen adaylarının öğretmenlik mesleğine ilişkin tutumları cinsiyet değişkenine göre anlamlı düzeyde farklılık göstermektedir $[\mathrm{t}(487)=.264, \mathrm{P}<.05]$. Bu bulgu genel kanının tersine erkek öğretmen adaylarının, öğretmenlik mesleğine ilişkin tutumlarının daha olumlu olduğunu göstermektedir. Öğretmen adaylarının öğretmenlik mesleğine ilişkin tutumları medeni durumlarına göre anlamlı düzeyde farklılık göstermemektedir. Öğretmen adaylarının, öğretmenlik mesleğine ilişkkin tutumları; branş, öğretmenliği tercih nedeni, interneti kullanım amacı ve yaşlarına göre anlamlı düzeyde farklılık gösterip göstermediği ile ilgili sayısal veriler Tablo 8'de yer almaktadır.

Tablo 8

Öğretmen Adaylarının Öğretmenlik Mesleğine İlişkin Tutumlarının; Branş Öğretmenliği Tercih Nedeni, Interneti Kullanım Amacı ve Yaşlarına Göre ANOVA Sonuçları

\begin{tabular}{|c|c|c|c|c|c|c|c|c|c|c|c|}
\hline Uygulama & Değişkenler & $\mathrm{n}$ & $\bar{X}$ & Ss & $\begin{array}{l}\text { Varyans } \\
\text { Kaynağ } 1\end{array}$ & $\begin{array}{l}\text { Kareler } \\
\text { Top. }\end{array}$ & sd & $\begin{array}{c}\text { Kareler } \\
\text { Ort. }\end{array}$ & $\mathrm{F}$ & $\mathrm{P}$ & $\mathrm{F}$ \\
\hline \multirow{9}{*}{ Branş } & 1.Tarih & 42 & 3.10 & .864 & \multirow{4}{*}{ Grup içi } & \multirow{9}{*}{35.806} & \multirow{4}{*}{7} & & \multirow{9}{*}{7.923} & \multirow{9}{*}{.000} & $1-5$ \\
\hline & 2.Edebiyat & 39 & 3.09 & .693 & & & & & & & $1-6$ \\
\hline & 3.Matematik & 52 & 3.39 & .876 & & & & & & & $2-5$ \\
\hline & 4.Coğrafya & 64 & 3.41 & .732 & & & & & & & $2-6$ \\
\hline & 5. Biyoloji & 97 & 3.81 & .790 & Gruplar aras1 & & 479 & 5.115 & & & $3-5$ \\
\hline & 6.İlahiyat & 100 & 3.56 & .843 & & & & & & & $4-5$ \\
\hline & 7.İktisadi idari & 36 & 3.60 & .885 & & & & & & & $5-8$ \\
\hline & 8.Sağlık & 57 & 3.02 & .726 & & & 486 & & & & $6-8$ \\
\hline & Toplam & 487 & 3.44 & .842 & & & & & & & $7-8$ \\
\hline \multirow{4}{*}{$\begin{array}{l}\text { Öğretmenli } \\
\text { ği Tercih } \\
\text { Nedeni }\end{array}$} & Kendi İsteğim & 221 & 3.52 & .830 & Grup ici & 5.107 & 2 & \multirow{4}{*}{2.554} & \multirow{4}{*}{3.636} & \multirow{4}{*}{.027} & \multirow{4}{*}{$1-3$} \\
\hline & Aile/Çevre & 157 & 3.29 & .869 & & & & & & & \\
\hline & İş Garantisi & 109 & 3.47 & .806 & Gruplar aras1 & 339.942 & 484 & & & & \\
\hline & Toplam & 487 & 3.44 & .842 & & 345.050 & 486 & & & & \\
\hline \multirow{5}{*}{$\begin{array}{l}\text { İnternet } \\
\text { Kullanma } \\
\text { Amacı }\end{array}$} & 1.Araştırma & 61 & 3.42 & .762 & \multirow{2}{*}{ Grup içi } & \multirow{2}{*}{8.253} & \multirow{2}{*}{3} & \multirow{2}{*}{2.751} & \multirow{5}{*}{3.945} & \multirow{5}{*}{.008} & \multirow{3}{*}{$1-2$} \\
\hline & 2. İletişim & 170 & 3.35 & .860 & & & & & & & \\
\hline & 3. Eğlence & 189 & 3.59 & .824 & \multirow{3}{*}{ Gruplar aras1 } & & & & & & \\
\hline & $\begin{array}{l}\text { 4. Bilgi } \\
\text { Edinme }\end{array}$ & 67 & 3.24 & .860 & & 336.796 & 483 & .697 & & & \multirow{2}{*}{$1-4$} \\
\hline & Toplam & 487 & 3.44 & .842 & & 345.050 & 486 & & & & \\
\hline \multirow{5}{*}{ Yaş } & 25 ve alt 1 & 50 & 3.48 & .780 & \multirow{2}{*}{ Grup içi } & \multirow{2}{*}{1.532} & \multirow{2}{*}{3} & \multirow{2}{*}{.511} & \multirow{5}{*}{.718} & \multirow{5}{*}{.541} & \multirow{5}{*}{-} \\
\hline & $26-30$ & 339 & 3.40 & .839 & & & & & & & \\
\hline & $31-35$ & 75 & 3.53 & .882 & \multirow{3}{*}{ Gruplar aras1 } & & & \multirow{3}{*}{.711} & & & \\
\hline & 36 ve üzer & 23 & 3.55 & .900 & & 343.517 & 483 & & & & \\
\hline & Toplam & 487 & 3.44 & .842 & & 345.050 & 486 & & & & \\
\hline
\end{tabular}

Tablo 8 genel olarak incelendiğinde, öğretmen adaylarının öğretmenlik mesleğine ilişkin tutumları; branşa [f(487) 7,923, $\mathrm{P}<.05]$, öğretmenliği tercih nedenine [f(487) 3,636, $\mathrm{P}<.05]$ ve interneti kullanım amacına [ $\mathrm{f}(487) 3,945, \mathrm{P}<.05]$ göre anlamlı düzeyde farklılık gösterdiği görülmektedir. Öğretmen adaylarının branşına göre baktığımızda, farkın tarih ile biyoloji arasında biyoloji lehine, tarihle ilahiyat arasında ilahiyat lehinde, edebiyat ile biyoloji arasında biyoloji lehine, edebiyat ile ilahiyat arasında ilahiyat lehinde, matematik ile biyoloji arasında biyoloji lehine, coğrafya ile biyoloji arasında biyoloji lehine, biyoloji ile sağlık arasında biyoloji lehine, ilahiyat ile sağlık ilahiyat lehine ve iktisat ile sağlık arasında iktisat lehinde olduğu görülmektedir. Öğretmen adaylarının Öğretmenliği Tercih Nedenlerine göre ise farkın kendi isteği ile tercih edenlerle, iş olanağı olduğu için tercih edenler arasında iş olanağı olduğu için tercih edenler lehinde farkın olduğu belirlenmiştir. Öğretmen adaylarının İnternet Kullanma Amacına göre baktığımızda farkın interneti araştırma amaçlı olarak kullananlar ile interneti iletişim amaçlı olarak kullananlar arasında interneti araştırma amaçlı olarak kullananlar lehinde ve 
interneti araştırma amaçlı olarak kullananlar ile bilgi edinme amaçlı olarak kullananlar arasında interneti araştırma amaçlı olarak kullananlar lehinde anlamlı bir farkın olduğu belirlenmiştir. Öğretmen adaylarının öğretmenlik mesleğine ilişkin tutumları; yaş [ $\mathrm{f}(487), 718, \mathrm{P}<.05]$, değişkenine göre anlamlı düzeyde farklılık göstermediği görülmektedir. Yaş değişkeni öğretmen adaylarının öğretmenlik mesleğine ilişkin tutumlarına etki eden bir faktör olmadığı söylenebilir.

\section{Öğretmen Adaylarının Pedagojik Yeterlik Algıları İle Öğretmenlik Mesleğine İlişkin Tutumları Arasındaki İlişki}

Öğretmen adaylarının pedagojik yeterlik algıları ile öğretmenlik mesleğine ilişkin tutumları arasındaki ilişki düzeyini belirlemek amacıyla yapılan varyans analizi sonucuna göre etkinin .05 anlamlılık düzeyinde anlamlı çıktığı belirlenmiştir $\mathrm{f}(485)=28,241, \mathrm{P}<.05]$. Bu anlamlı etkinin yönünü ve düzeyini belirlemek amacıyla yapılan korelasyon işlemi sonucunda elde edilen bulgular Tablo 9'da verilmiştir.

Tablo 9.

Öğretmen Adaylarının Pedagojik Yeterlik Algıları İle Öğretmenlik Mesleğine İlişkin Tutumları Arasındaki İlişki

\begin{tabular}{lcc}
\hline Değişkenler & $\overline{\mathrm{X}}$ & Ss \\
\hline Öğretmen Adaylarının Pedagojik Yeterlik Algıları & 3.20 & .533 \\
Öğretmen Adaylarının Öğretmenlik Mesleğine İlişkin Tutumları & 3.44 & .842 \\
\hline
\end{tabular}

Öğretmen Adaylarının Pedagojik Yeterlik Algıları İle Öğretmenlik Mesleğine İlişkin Tutumlarına ilişkin elde edilen verilerin aritmetik ortalamaları karşılaştırmalı olarak incelendiğinde; Öğretmen Adaylarının Öğretmenlik Mesleğine İlişkin Tutum ortalamalarının $(\overline{\mathrm{x}}=3,44)$, Pedagojik Yeterlik Algılarının aritmetik ortalamaları ise $(\overline{\mathrm{x}}=3.20)$ olduğu görülmektedir. Öğretmen Adaylarının hem Öğretmenlik Mesleğine İlişkin Tutumları hem de Pedagojik Yeterlik Algıları beklenilen düzeyde olmadığ1 görülmektedir. Buna rağmen Öğretmen Adaylarının Öğretmenlik Mesleğine İlişkin Tutumlarının Pedagojik Yeterlik Algılarına göre daha olumlu olduğu belirlenmiştir. Öğretmen Adaylarının Pedagojik Yeterlik algılarının yordanmasına ilişkin çoklu doğrusal regresyon sonuçları Tablo 10'da verilmiştir.

Tablo 10.

Öğretmen Adaylarının Pedagojik Yeterlik Algısının Yordanmasına İlişkin Regresyon Analizi Sonuçları

\begin{tabular}{lccccccc}
\hline Değişkenler & $B$ & $S h$ & $\beta$ & $T$ & $p$ & Ikkili $r$ & Klsmi $r$ \\
\hline Sabit & 1.680 & .059 & & 28.241 & .000 & & \\
$\begin{array}{l}\text { Öğretmen Adaylarının } \\
\text { Öğretmenlik Mesleğine }\end{array}$ & .535 & .020 & .770 & 26.592 & .000 & .770 & .770 \\
\begin{tabular}{l} 
İlişkin Tutumları \\
\hline
\end{tabular} & & & & & & & \\
\hline
\end{tabular}

$F R(1-485) R=28,241, p<.01, R=, 770, R P 2 P=, 592$

Öğretmen adaylarının pedagojik yeterlik algıları ile öğretmenlik mesleğine ilişkin tutumları arasında yüksek düzeyde anlamlı bir ilişkinin olduğu görülmektedir $(\mathrm{R}=, 77, \mathrm{p}<.01)$. öğretmenlik mesleğine ilişkin tutum, Öğretmen Adaylarının Pedagojik Yeterlik Algısındaki toplam varyansın yaklaşık \% 59'ünü açıklamaktadır. Yine öğretmenlik mesleğine ilişkin tutumlar $(\beta=, 770, p<.01)$ Öğretmen adaylarının pedagojik yeterlik algılarını pozitif yönde ve anlamlı düzeyde yordamaktadır. Pedagojik yeterlik algıları ile öğretmenlik mesleğine ilişkin tutumlar arasındaki ikili ve kısmi korelâsyonlar incelendiğinde pedagojik yeterlik algıları ile öğretmenlik mesleğine ilişkin tutumlar arasında pozitif yönde ve yüksek düzeyde bir ilişkinin $(\mathrm{r}=.77)$ olduğu görülmektedir. Regresyon katsayılarının anlamlılığına ilişkin t-testi sonuçlarına göre öğretmen adaylarının pedagojik yeterlik algıları, öğretmenlik mesleğine ilişkin tutumlar değişkenini anlamlı düzeyde yordadığı söylenebilir.

\section{TARTIŞMA ve SONUÇLAR}

Ulaşılan verilerin yorumlanması sonucu elde edilen bulgulara dayalı olarak, öğretmen adaylarının pedagojik yeterlik algılarının orta düzeyde olduğu görülmüştür. Pedagojik yeterliğin alt boyutları açısından bakıldığında öğretmen adaylarının kendilerini en zayıf hissettikleri alan "Dersi Sonuçlandırma Etkinlikleri" alanı olurken, bunu "Ders Öncesi Etkinlikler”, "Derse Hazırlık Etkinlikleri” ve "Dersi Geliştirme Etkinlikleri” izlemektedir. Öğretmen adaylarının genel olarak 
pedagojik yeterlik algılarının beklenilen düzeyde olmadığı söylenebilir. Öğretmen adaylarının özellikle dersi sonuçlandırma etkinlikleri açısından ciddi bilgi ve beceri ihtiyacında oldukları anlaşılmıştır. Öte yandan, öğretmen adaylarının pedagojik yeterlik algıları; cinsiyet, medeni durum, branş, öğretmenliği tercih nedeni, interneti kullanım amacı ve yaşlarına göre anlamlı düzeyde farklılık göstermediği belirlenmiştir. Öğretmenlik mesleğinin gerektirdiği davranış formları, bilgi ve beceriler herkes için geçerli olduğundan adayların kişisel özelliklerine göre farklılık göstermediği söylenebilir. Dündar ve Kara (2013) öğretmen adayları üzerinde yaptıkları araştırmaya göre, pedagojik formasyon derslerinin gereksiz olduğu, verimsiz geçtiği kanısında oldukları belirlenmiştir. Yaman (2010) pedagojik formasyon almamış öğretmenlerin, sınıf yönetimi uygulamalarında tecrübeye ya da bilgi eksikliğine dayalı yetersizlikler yaşadıklarını belirlemiştir. Kara ve sağlam (2014). Araştırmalarında, öğretmenlik meslek bilgisi derslerinin, MEB'in belirlediği gereksinimlere uygun olduğunu belirlemişlerdir. Çapri ve Çelikkaleli (2008) çalışmalarında öğretmen adaylarının cinsiyetleri onları mesleki yeterlik algılarına ve tutumlarına etki ettiği belirlenmiştir.

Toplanan veriler üzerinde yapılan istatistiksel analizler, öğretmen adaylarının öğretmenlik mesleğine iliş̧kin tutumlarının orta düzeyde olduğunu göstermiştir. Öğretmen adaylarının öğretmenlik mesleğine iliş̧kin tutumları, pedagojik yeterlik algılarından daha yüksek olmasına rağmen beklenilen düzeyde olmamıştır. Bu sonuç, (Oğuz, 2013; Tanel, vd, 2007; Altınkurt, vd, 2014; Özder, vd, 2010) çalışmalarının sonuçlarıyla örtüşmektedir. Öğretmen adaylarının öğretmenlik mesleğine ilişkin tutumları medeni durumlarına göre anlamlı düzeyde farklılık göstermezken, cinsiyet durumlarına göre beklenilenin tersine erkek adaylarında lehinde anlamlı bir farklılık ortaya çıkmıştır. Bu sonuç, (Aksoy, 2010; Durmuşoğlu vd. 2009; Oral, 2004; Pehlivan, 2008; Akkaya, 2009; Özbek, 2007; Yüksel, 2004; Aksoy, 2010; Sağlam, 2008) çalışmalarının sonuçlarıyla örtüşürken, (Açışlı, Kolomuç, 2012; Bulut, 2009; Tanel vd. 2007; Gömleksiz vd. 2006; Gürbüztürk ve Genç, 2004; Başbay vd. 2009) çalışmalarının sonuçlarıyla örtüşmediği görülmektedir.

Öğretmen adaylarının öğretmenlik mesleğine ilişkin tutumları; branşa, öğretmenliği tercih nedenine ve interneti kullanım amacına göre anlamlı düzeyde farklılık gösterdiği belirlenmiştir. Öğretmen adaylarının branşına göre baktığımızda, farkın biyoloji branşındaki adaylar ile diğer branşlardaki adaylar arasında biyoloji branşındakilerin lehinde ortaya çıkmıştır. Böylece biyoloji branşındaki öğretmen adaylarının öğretmenlik mesleğine karşı tutumları diğer branşlara göre daha olumlu olduğu söylenebilir. Öğretmen adaylarının öğretmenliği tercih nedenlerine baktığımızda ise, farkın kendi isteği ile tercih edenlerle, iş olanağı olduğu için tercih edenler arasında iş olanağı olduğu için tercih edenler lehinde olduğu belirlenmiştir. Bu sonuçta aslında beklenilen bir sonuç değildir. Çünkü genellikle kendi isteği ile öğretmenliği tercih edenlerin öğretmenlik mesleğine karşı tutumlarının daha olumlu olması gerekmektedir. Ancak bu çalışmada iş olanağı olduğu için öğretmenliği tercih ettim diyenlerin öğretmenlik mesleğine ilişkin tutumlarının daha yüksek olduğu görülmüsştür. Öğretmen adaylarının İnternet Kullanma Amacına göre farkın interneti araştırma amaçlı olarak kullananlar ile interneti diğer amaçlar için kullananlar arasında interneti araştırma amaçlı olarak kullananlar lehinde olduğu belirlenmiştir. İnterneti araştırma amaçlı olarak kullanan öğretmen adaylarının öğretmenlik mesleğine ilişkin tutumlarının daha olumlu olduğu söylenebilir. Can (2010) çalışmasında öğretmen adaylarının öğretmenlik mesleğine ilişkin tutumlarının oldukça yüksek olduğu ve cinsiyetin belirleyici bir faktör olmadığı tespit edilmiştir.

Öğretmen adaylarının pedagojik yeterlik algıları ile öğretmenlik mesleğine ilişkin tutumlarına karşılaştırmalı olarak incelendiğinde; Öğretmen Adaylarının Öğretmenlik Mesleğine İlişkin Tutum ortalamalarının, Pedagojik Yeterlik Algılarından daha olumlu olduğu görülmüsstür. Ancak, öğretmen adaylarının hem öğretmenlik mesleğine ilişkin tutumları hem de pedagojik yeterlik algıları beklenilen düzeyde olmadığı sonucuna ulaşılmıştır. Öğretmen adaylarının pedagojik yeterlik algıları ile öğretmenlik mesleğine ilişkin tutumları arasında yüksek düzeyde, pozitif yönde anlamlı bir ilişkinin olduğu görülmüsstür. Öğretmenlik mesleğine ilişkin tutum, Öğretmen Adaylarının Pedagojik Yeterlik Algısındaki toplam varyansın yaklaşık olarak yarısından fazlasını açıklamaktadır. Regresyon katsayılarının anlamlılığına ilişkin t-testi sonuçlarına göre öğretmen adaylarının pedagojik yeterlik algıları, öğretmenlik mesleğine ilişkin tutumlar değişkenini anlamlı düzeyde yordadığ 1 söylenebilir. Ayık ve Ataş (2014). Araştırmalarında, Öğretmen adaylarının öğretmenlik mesleğine yönelik tutumlarının oldukça olumlu ve öğretme motivasyonlarının ise orta düzeyde olduğunu belirlemişlerdir. Usta ve Korkmaz (2010). Çalışmalarında, Öğretmen adaylarının bilgisayara yeterlilik düzeylerine 
ilişkin alg1 düzeylerine bağlı olarak hem öğretmenlik mesleğini sevmeye hem değer vermeye hem de uyuma ilişkin tutum puanları artış gösterdiğini belirlemişlerdir.

\section{KAYNAKLAR}

Altınkurt, Y. Y1lmaz, K. \& Erol, E. (2014). Pedagogic Formation Program Students’ Motivations for Teaching Profession. Trakya University Journal of Education , 4(1), 48-62.

Akkaya, N. (2009). Öğretmen Adaylarının Öğretmenlik Mesleğine Yönelik Tutumlarının Bazı Değişkenlere Göre İncelenmesi, Dokuz Eylül Üniversitesi Buca Eğitim Fakültesi Dergisi, 25, 35-46.

Aksoy, M.E. (2010). Öğretmen Adaylarının Öğretmenlik Mesleğine İlişkin Tutumları (Gaziosmanpaşa Üniversitesi Örneği. Sosyal Bilimler Araştırmaları Dergisi. 2, 197-212.

Açışlı, S. \& Kolomuç, A. (2012). Sınıf Öğretmeni Adaylarının Öğretmenlik Mesleğine Yönelik Tutumlarının İncelenmesi, Ë̆itim ve Öğretim araştırmaları dergisi, 1(2). 266-271.

Ayık, A. \& Ataş, Ö. (2014). Öğretmen Adaylarının Öğretmenlik Mesleğine Yönelik Tutumları İle Öğretme Motivasyonları Arasındaki İlişki. Eğitim Bilimleri Araşstırmaları Dergisi, 4 (1) 25-43.

Aşkar, P. \& Erden, M. (1987) Öğretmenlik Mesleğine Yönelik Tutum Ölçeği, Çağdaş Eğitim. 121 (12), 8-11.

Başbay, M., Ünver, G. \& Bümen, N.T. (2009). Ortaöğretim Alan Öğretmenliği Tezsiz Yüksek Lisans Öğrencilerinin Öğretmenlik Mesleğine Yönelik Tutumları: Boylamsal Bir Çalışma, Kuram ve Uygulamada Eğitim Yönetimi, 59, 345-366.

Bıçak, B. \& Nartgün, Z. (2009). Özel alan yeterlikleri ile buna dayalı bireysel ve kurumsal performans değerlendirme ölçütlerinin belirlenmesi. Performans Yönetimi: Bireysel Performans Yönetimi Komisyonu II. Dönem Raporu. Ankara: MEB Öğretmen Yetiştirme ve Eğitimi Genel Müdürlüğü. http://otmg.meb.gov.tr/belgeler/raporlar.pdf. Erişim tarihi: 29.08.2013.

Bulut, İ. (2009). Öğretmen Adaylarının Öğretmenlik Mesleğine İlişkin Tutumlarının Değerlendirilmesi (Dicle ve Firat Üniversitesi Örneği). Dicle Üniversitesi Ziya Gökalp Eğitim Fakültesi Dergisi, 13-24.

Can, Ş. (2010). Tezsiz Yüksek Lisans Öğrencilerinin Öğretmenlik Mesleğine Yönelik Tutumları. Muğla Üniversitesi Sosyal Bilimler Enstitüsü Dergisi, (24), 13-28.

Chigona, W \& Davids, Z. (1014). Educators' motivation on integration of ICTs into pedagogy: case of disadvantaged areas, South African Journal of Education, 34, (3) 859-867.

Colby, A. \& Kohlberg, L,. (1987). The Measurement of Moral Judgment. Vol. I: Theoretical Foundations and Research Validation. Cambridge University Press. New York.

Çeliköz, N. \& Çetin, F. (2004). Anadolu Öğretmen Lisesi Öğrencilerinin Öğretmenlik Mesleğine Yönelik Tutumlarını Etkileyen Etmenler. Milli Eğitim Dergisi, 162, 160-167.

Çapraz, C. \& Samanc1, O. (2014 ). The Attitudes of Trainee Primary School Teachers Towards Their Proffesion and the Feelings that They Have on the First Practice Day at School, Atatürk Üniversitesi Sosyal Bilimler Enstitüsü Dergisi, 18 (1): 179-188

Çapri, B. \& Çelikkaleli, Ö. (2008). Investıgatıon Of Preservıce Teachers' Attıtudes Towards Teachıng And Professional Self-Efficacy Beliefs Accordıng To Their Gender, Programs, And Faculties, İönü Üniversitesi Eğitim Fakültesi Dergisi, 9 (15)33-53.

Doğan, T. \& Çoban, A.E., (2009). The Investigation of the Relations Between Students' Attitude Toward Teaching Profession and Anxiety Level in Faculty of Education, Eğitim ve Bilim Education and Science, 34(153), 157-168.

Dündar, H. \& Karaca, E.T. (2013). Formasyon Öğrencilerinin 'Pedagojik Formasyon Programı'na İliş̧kin Sahip Oldukları Metaforlar. Gazi Üniversitesi Endüstriyel Sanatlar Eğitim Fakültesi Dergisi,(30),19-34

Erden, M.(1998). Öğretmenlik Mesleğine Giriş. İstanbul: Alkım Yayınları.

Eren, B., Çelik, M. \& Oğuz, A. (2014). Investigation Of Dissertations And Articles In Turkey About The Attitudes Towards Teaching Profession, Dumlupinar University Journal of Social Sciences, 42, 359-370.

Fukuyama, F. (1998). Güven: Sosyal Erdemler ve Refahın Yaratılması. (Çev. Ahmet Buğdaycı). TíB Yayını. Ankara. 1998. s.59. Kara, D. A. \& Sağlam, M. (2014). Evaluation of Professional Teaching Knowledge Courses in Terms of Competencies Regarding the Learning and Teaching Process, Journal of Qualitative Resarch in Education, 2(3), 28-86.

Kara, A.D. \& Sağlam, S. (2014). Öğretmenlik Meslek Bilgisi Derslerinin Öğrenme-Öğretme Sürecine Yönelik Yeterlikleri Kazandırması Yönünden Değerlendirilmesi, Eğitimde Nitel Araştırmalar Dergisi ENAD, 2(3) 28-86.

Kocaarslan, M. (2014). Analysis of Prospectıve Teachers' Attitudes Towards Teachıng As a Profession. Asya Ögretim Dergisi Www.E-Aji.Com [Asian Journal Of Instruction], 2(1), 46-55

Girgin, G., Akamca, G. Ö. Ellez, A. M. \& Oğuz, E. (2010). Preschool Teacher Candidates’ Attttudes Towards Profession, Sel Efficacy Beliefs And Professional Self Respects, Buca Eğitim Fakültesi Dergisi, 28, 1-11.

Güngör, E. (1990). Dünden Bugünden Tarih-Kültür-Milliyetçilik.İstanbul: Ötüken Neşriyat. 
Gürbüztürk, O. \& Genç, S. Z. (2004). Öğretmen Adaylarının Öğretmenlik Mesleğine İlişkin Görüşleri. İnönü Üniversitesi Ĕ̌itim Fakültesi Dergisi, 5 (7), 47-62.

Lundgren, B., Scheckle, E \& Zinn, D. (2015). Teachers' professional development: Awareness of literacy practices, South African Journal of Education, 35, (1), 945-956.

Lawrence Kohlberg.(1973). “Continuities in Childhood and Adult Moral Development Revisited”. in P. B. Baltes and K. W. Schaie (eds.) Life-span Developmental Psychology: Personality and Socialization. Academic Press. New York. 187-196.

McKeachie, W. J. (1997). Critical Elements İn Training University Teachers. International Journal of Academic Development, 2(1), 67-74.

Oktay, A. (1991). Değişen Toplumlarda Aile ve Eğitim. Sosyo-Ekonomik Yönü İle Aile Sempozyumu. İstanbul.

Oktay, A. (1999). Yaşamın Sihirli Yılları: Okul Öncesi Dönem. İstanbul:Epsilon Yayıncılık.

Oğuz, E. (2013). The Relationship Between Classroom Management Styles of Pre-Service Teachers and Their Attitude of Teaching Profession. Trakya University Journal of Education, 3, (2), 12-20.

Öncül, R. (2000), Eğitim ve Eğitim Bilimleri Sözlüğü, İstanbul, MEB. Yayınları.

Özder, H., Konedralı, G. \& Zeki, C.P. (2010). Öğretmen Adaylarının Öğretmenlik Mesleğine Yönelik Tutumlarının Çeşitli Değişkenler Açısından İncelenmesi, Educational Administration: Theory and Practice 16, (2), 253- 275.

Usta, E. \& Korkmaz, Ö. (2010). Öğretmen adaylarının bilgisayar yeterlikleri ve teknoloji kullanımına ilişkin algıları ile öğretmenlik mesleğine yönelik tutumları. Uluslar arası İnsan Bilimleri Dergisi, 7(1), 13351349.

Üstüner, M. (2006), Öğretmenlik Mesleğine Yönelik Tutum Ölçeğinin Geçerlik ve Güvenirlik Çalışması, Kuram ve Uygulamada Ĕ̆itim Yönetimi, (45), 109-127.

Özbek, R. (2007). Öğretmen Adaylarının Öğretmenlik Mesleğini Tercih Etmelerinde Kişisel, Ekonomik ve Sosyal Faktörlerin Etkililik Derecesine İlişkin Algıları. Firat Üniversitesi Sosyal Bilimler Dergisi, Cilt 17, Sayl 1, s. 145-159.

Pehlivan, K. B. (2008), Sınıf Öğretmeni Adaylarının Sosyo-kültürel Özellikleri ve Öğretmenlik Mesleğine Yönelik Tutumları Üzerine Bir çalışma, Mersin Üniversitesi Ĕgitim Fakültesi Dergisi, 4(2): 151-168.

Sağlam, A.Ç. (2008). Müzik Öğretmenliği Bölümü Öğrencilerinin Öğretmenlik Mesleğine Yönelik Tutumları. Yüzüncü Yıl Üniversitesi Eğitim Fakültesi Dergisi, 5, (1). 59-69.

Sherman K \& Howard SK 2012. Teachers' Beliefs about First- and Second-Order Barriers to ICT Integration: Preliminary Findings from a South African Study. 23rd International Conference of Society for Information Technology and Teacher Education. Charlottesville, VA: Association for the Advancement of Computing in Education.

Sünbül, A. M. (2001) Bir Meslek Olarak Öğretmenlik. Öğretmenlik Mesleğine Giriş. (Edit: Ö. Demirel-Z. Kaya) Ankara: Pegem Yayıncilık.

Şengün M, \& Kaya M (2007). The Scale of Moral Maturity: The study of Its Validity and Reliability. Ondokuz Mayis Univ. Fac. Theol. J. 24(25):51-64.

Tanel, R. , Şengören, S. K. \& Tanel, Z., (2007), Fizik Öğretmen Adaylarının Öğretmenlik Mesleğine İlişskin Tutumlarının Farklı Değişkenler Açısından İncelenmesi, Pamukkale Üniversitesi Eğitim Fakültesi Dergisi, 2 (22), 1-9.

Tekerek, M. \& Polat, S. (2011). Preservice Teachers Attıtudes Towards Teaching Profession 5th International Computer \& Instructional Technologies Symposium, 22-24 September 2011, Frrat University, Elazı̆ $/$ Turkey

Temel,R., Şengören, K. S. \& Tanel, Z. ( 2007). Fizik Öğretmen Adaylarının Öğretmenlik Mesleğine İlişkin Tutumlarının Farklı Değişkenler Açısından İncelenmesi, Pamukkale Üniversitesi Eğitim Fakültesi Dergisi, (2) 22,1-9.

Thomas E. L. (1991). Educating for Character: How Our Schools can Teach Respect and Responsibility. Bantam Books. New York.

TDK-Türk Dil Kurumu (2015). Web: http://tdk.gov.tr/index.php? =yazim_listeli\&ayn1=icn\&kelime1=pedagoji, Erişim Tarihi 11.03.2015.

Tufan, E. \& Güdek, B. (2008). Müzik Öğretmenliği Mesleğine Yönelik Tutum Ölçeğinin Geliştirilmesi. Türk Ĕ̆itim Bilimleri Dergisi, 6 (1), 25-40.

Yaman,B.(2010). Pedagojik Formasyon Eğitimi Almamış Öğretmenlerin Sınıf Yönetimi Algıları / Aksaray İli Örneği. Electronic Journal of Social Sciences, 9(31) 53-72

Yapıcı, M. \&Yapıcı, Ş. (2013). Pre-Servıce Teachers' Conceptual Metaphors About Pedagogical Formation Program, Turkish Studies - International Periodical For The Languages, Literature And History of Turkish or Turkic, 8(8) 1421-1429. Yüksel, S. (2004). Tezsiz Yüksek Lisans Programının Öğrencilerin Öğretmenlik Mesleğine İlişkin Tutumlarına Etkisi, Uludağ Üniversitesi eğitim Fakültesi Dergisi, XVII(2), 355-379. 
EK 1.

PEDAGOJIK YETERLIK ALGISI ÖLÇEĞİ

\begin{tabular}{|c|c|c|c|c|c|c|}
\hline \multicolumn{2}{|c|}{ Pedagojik Yeterlik Algısı Ölçeği } & 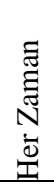 & 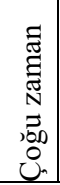 & 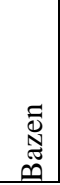 & 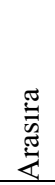 & 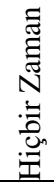 \\
\hline \multicolumn{7}{|c|}{ Ders Öncesi Hazırlık Çalışmaları } \\
\hline 1 & Ders öncesi sınıf temizliğine özen gösterme. & & & & & \\
\hline 2 & Dersin özelliğine uygun olarak ders öncesi yeteri kadar hazırlık yapma. & & & & & \\
\hline 3 & Derse başlamadan önce sınıf kurallarını ögrencilerle belirleme & & & & & \\
\hline 4 & Sınıfta olası istenmeyen davranışlara karşı önceden önlem alma. & & & & & \\
\hline \multicolumn{7}{|c|}{ Dersin Giriş Etkinlikleri } \\
\hline 5 & Öğrencilerin yararlanacakları kaynaklar ile ders araç gereçlerini hazırlama. & & & & & \\
\hline 6 & Derste işlenecek konu hakkında öğrencilerin neler bildiklerini öğrenmeye çalışma. & & & & & \\
\hline 7 & $\begin{array}{l}\text { Derse başlarken öğrencilerin ilgisini çekecek ve derse katılımlarını sağlayacak bir } \\
\text { başlangıç yapma. }\end{array}$ & & & & & \\
\hline 8 & Öğrencilerin konuyu öğrenmeleri için merak ve güdülerini harekete geçirme. & & & & & \\
\hline 9 & $\begin{array}{l}\text { Sinıfta işlenecek konuya uygun öğretim ortamı oluşturmaya yönelik fiziksel düzenlemeler } \\
\text { yapma. }\end{array}$ & & & & & \\
\hline 10 & Dersin amaçlarını belirleme ve ön öğrenmelerle ilişkilendirme. & & & & & \\
\hline 11 & Dersin başında öğrenciyi derse hazırlayıcı etkinlikler yapma. & & & & & \\
\hline 12 & $\begin{array}{l}\text { Öğrencilerin kendilerini özgürce ifade edebilecekleri demokratik bir öğrenme ortamı } \\
\text { oluşturma }\end{array}$ & & & & & \\
\hline \multicolumn{7}{|c|}{ Dersin Geliştirme Etkinlikler } \\
\hline 13 & Koşullara uygun öğretim yöntem ve tekniklerini seçip kullanma & & & & & \\
\hline 14 & Öğrencilerin yaptıkları hataları birer öğrenme firsatı olarak görme. & & & & & \\
\hline 15 & Demokratik tutum ve davranışlara özen gösterme. & & & & & \\
\hline 16 & Öğrencilerin görüşlerine karşı hoşgörülü ve saygılı davranma. & & & & & \\
\hline 17 & Öğrencilere tutarlı ve dengeli davranma. & & & & & \\
\hline 18 & Ders hızını öğrencinin öğrenme düzeyine göre ayarlama & & & & & \\
\hline 19 & Ses tonunu ve vurgulamaları uygun şekilde ayarlama. & & & & & \\
\hline 20 & Öğrencilerin, yanıt ve yorumlarını sabırla dinleme. & & & & & \\
\hline 21 & Önemli söylem ve davranışları sıkça tekrarlama. & & & & & \\
\hline 22 & Sınıftaki her öğrenciye ismiyle hitap etme. & & & & & \\
\hline \multicolumn{7}{|c|}{ Dersin Sonuç Etkinlikleri } \\
\hline 23 & Ölçme sonucunda öğrencilerin yanlış ve hatalarını gösterip düzeltme. & & & & & \\
\hline 24 & Dersin sonunda öğrencilerin ne öğrendiğini, hangi davranışları kazandığını kontrol etme. & & & & & \\
\hline 25 & Dersin ne zaman biteceğini öğrencilere birkaç dakika önceden bildirme. & & & & & \\
\hline 26 & Öğretmenin, bütün öğrenciler sınıftan ayrıldıktan sonra sınıftan ayrılma. & & & & & \\
\hline 27 & Öğrencileri değerlendirmede katı sınırlamalar yerine alternatifler sunma. & & & & & \\
\hline 28 & Değerlendirme biçim ve kurallarını öğrencilerle belirleme & & & & & \\
\hline 29 & Süreç değerlendirme yaklaşımlarını benimseme & & & & & \\
\hline
\end{tabular}

